The 2019 Annual Meeting of the AESJ

The 2nd Joint Symposium organized by the Cooperation Committee and International Committee

\title{
Principles and Policy Development of the Basic Law on Food, Agriculture and Rural Areas: Achievement and Future
}

\section{Shirara Shiokawa ${ }^{1}$}

This study reviews the background of the Basic Law on Food, Agriculture and Rural Areas formulation, the aim of the new basic law, and the agricultural policy for 20 years, and introduces the research results of the main policies of the Policy Research Institute, Ministry of Agriculture, Forestry and Fisheries (PRIMAFF).

Key words: basic plan, food self-sufficiency ratio, business farmers, farming income stabilization measures, direct payment to farmers in hilly and mountainous areas

\section{Introduction}

Twenty years have passed since the Food, Agriculture and Rural Basic Law was enacted I examined the remaining issues and looked forward by reviewing the 20-year agricultural policy and looking at the results of research on the main policies of the National Policy Research Institute of Agriculture, Forestry and Fisheries.

\section{Features of the New Basic Law}

The new basic law consists of four pillars: securing a stable food supply, fulfillment of multifunctional roles, sustainable agricultural development that supports these, and development of rural areas.

There are six points in the new basic law: 1) the formulation of the Basic Plan for Food, Agriculture and Rural Areas, setting targets for the food self-sufficiency ratio, 2) development of consumer-oriented food policies, 3) establishment of desirable agricultural structures and development of policy for management, 4) prices that appropriately reflect market evaluations and farming income stabilization measures, 5) maintenance and promotion of the natural circulation function, and 6) compensation for disadvantageous production conditions in hilly and mountainous areas.

\section{The Basic Plans for Food, Agriculture and Rural Areas and Development of Measures}

The basic plan is a program for developing specific measures in line with the basic philosophy of the New Basic Law, and is formulated every five years, taking into account changes in the situation. Various measures have been taken based on the basic plan.

\section{1) Food sector}

In 2003, the Food Safety Basic Act was enacted and the concept of risk analysis was introduced. In 2009, the Rice Traceability Act was enacted in response to the problem of irregular distribution of rice grains. Since 2007, the Good Agricultural Practice (GAP) and HACCP methods have been promoted.

Due to concerns about the loss of nutritional balance and increased lifestyle-related diseases, the Dietary Guidelines were formulated in 2000 and a Guide to a Balanced Diet was formulated in 2005. The Basic Law on Food and Nutrition Education was enacted in 2005.

As for food labeling, the labeling of the origin of fresh food was made mandatory in 2000 , the labeling of raw material names of processed foods was made mandatory in 2001, and the labeling of the origin of all processed foods was mandatory in 2017.

From the viewpoint of strengthening the business foundation of the food industry, the deadline of the Act on Temporary Measures for Improvement of the Agricultural Products Processing Industry was extended, the Food Communication Project was promoted, and the global expansion of the food industry was supported. The Agricultural Competitiveness Strengthening Support Law was enacted in 2017 to support the reorganization of the food industry.

The Act to Promote Cooperation between Agriculture,

\footnotetext{
${ }^{1}$ The Policy Research Institute, Ministry of Agriculture, Forestry and Fisheries (PRIMAFF) shirara_shiokawa680@maff.go.jp
} 
Principles and Policy Development of the Basic Law on Food, Agriculture and Rural Areas: Achievement and Future 37

Manufacturing and Commerce in 2008, the AFFrinnovation Act in 2010, and the Agriculture, Forestry and Fisheries Fund Corporation for Innovation, Value-chain and Expansion Act in 2012 were enacted.

In order to stabilize and diversify imports, information was exchanged with importing countries, surveys on alternative importing countries, and guidelines for promoting foreign investment were made. The WTO has been engaged in Doha Round negotiations since 2001. As of Deceber 2018, 18 EPAs / FTAs have been concluded with 21 countries and regions. Export strategies including market research and export environment improvement were formulated in 2004, and the export value increased to 906.8 billion yen in 2018 .

The Food Security Manual for shortages was formulated in 2002 to deal with unforeseen situations and revised as the Emergency Food Security Guidelines in 2012.

\section{2) Agriculture field}

The introduction of the corporation to agriculture was approved as a form of agricultural production corporation in 2000. The introduction of the general corporations to agriculture was approved using the lease method in a special zone for structural reforms in April 2003 and nationwide in 2005.

Since 2012, the People and Farmland Plans have been created, and in 2013 the Farmland Intermediate Management Law was enacted to accelerate the accumulation of farmland.

A rice production target quantity allocation method was introduced and efforts were made to develop production areas based on local creativity in April 2004. In 2007, CrossCommodity Measures to Stabilize Agriculture Business were introduced in order to focus measures on those who are motivated. Since 2011, a Household Income Compensation System was implemented for sales farmers. The management income stabilization measures were reviewed in December 2013, and the target of focus became certified farmers, certified new farmers, and community farming. In 2018, the direct payment grant for rice was abolished.

In the maintenance and promotion of the natural circulation function of agriculture, the Comprehensive Biomass Nippon Strategy was decided in December 2002, and revised in March 2006 after the Kyoto Protocol entered into force in February 2005. The Fundamental Law of Promoting Usage of Biomasswas was enacted in 2009, and the Biomass Industry City Concept is underway.

\section{3) Rural field}

A Direct Payment System for Hilly and Mountainous
Areas was started in order to directly compensate for disadvantages in agricultural production conditions in 2000. A Hilly and Mountainous Areas Renaissance Project has been implemented to prioritize various projects and relax requirements since 2017.

The Special Law for the Prevention of Damage to Birds and Animals was enacted in 2007 and revised to secure the personnel for capturing birds and animals in 2012.

The Land Improvement Law was revised in 2001 in order to be in harmony with the environment in the development of fields and agricultural irrigation facilities.

A Measures to Conserve and Improve Land, Water and the Environment were introduced to support efforts to conserve and manage farmland / agricultural water in 2007. A support for local resource conservation management (Agricultural Land Maintenance Payment) was newly established in 2014. It was integrated with the support for efforts to improve quality (Resource Improvement Payment), a Direct Payment System for Hilly and Mountainous Areas and the Environmental Conservation Agriculture Direct Payment, as the Japanese Direct Payment System.

In order to revitalize rural areas, the Vision for Revitalizing Farming and Fishing Villages was formulated in 2015.

After Renewable Energy Law was enacted and the fixed price purchase system was started in 2013, greatly improving the profitability of the project.

The Symbiosis and Convection Promotion Conference between Cities and Rural and Fishing Villages (All Right! Nippon Conference) was established in 2002 to promote the national movement to promote the symbiosis and convection between cities and farming and fishing villages. The Agricultural and Mountain Fishing Village Revitalization Law was enacted in 2007, and subsidies were started for local efforts to revitalize agricultural and fishing villages. The Children's Farm and Mountain Fishing Village Exchange Project has been underway since 2008 .

\section{Food Self-sufficiency Ratio}

The calorie-based food self-sufficiency ratio, the production-output-based food self-sufficiency ratio, and the feed self-sufficiency ratio are set as targets in the basic plan. The 2015 basic plan targets 45\%, 73\%, and 40\% in FY2025, respectively.

The calorie-based self-sufficiency ratio has fallen from $40 \%$ in 1998 to $38 \%$ in 2017 . The main reason for the decline is the decrease in rice consumption. The production-output- 
based food self-sufficiency ratio dropped from $70 \%$ in 1998 to $65 \%$ in 2017 . The main reason for the decline is the decrease in the consumption of vegetables and rice and the increase in the consumption of meat that exceeds domestic production. The feed self-sufficiency ratio has remained almost unchanged from 25\% in 1998 to $26 \%$ in 2017.

The food self-sufficiency rate has a certain limit as an indicator of the potential food production capacity of the agriculture, forestry and fisheries industry. The food selfsufficiency index was shown in the 2015 basic plan. The calorie maximized by planting mainly potatoes reaches the estimated energy requirement $(2,145 \mathrm{kcal} /$ person / day) in fiscal 2017. However the calorie maximized by planting rice, wheat, and soybeans is below the estimated energy requirement.

Table 1. Self-sufficiency ratio and production

\begin{tabular}{|c|c|c|c|}
\hline \multicolumn{4}{|c|}{ (unit:\%, thousand ton) } \\
\hline & 2013 & 2017 & $\begin{array}{c}2025 \\
\text { (Target) }\end{array}$ \\
\hline \multicolumn{4}{|c|}{ Self-sufficiency Ratio } \\
\hline Calorie-based & 39 & 38 & 45 \\
\hline $\begin{array}{l}\text { Production-output- } \\
\text { based }\end{array}$ & 65 & 65 & 73 \\
\hline Feed & 26 & 26 & 40 \\
\hline \multicolumn{4}{|l|}{ Production } \\
\hline Rice & 8,589 & 7,797 & 7,520 \\
\hline Wheat & 812 & 907 & 950 \\
\hline Soybeans & 200 & 253 & 320 \\
\hline Sweet potatoes & 942 & 807 & 940 \\
\hline Potatoes & 2,408 & 2,395 & 2,500 \\
\hline Veritables & 11,781 & 11,707 & 13,950 \\
\hline Fruit & 3,035 & 2,792 & 3,090 \\
\hline Sugar beets & 3,435 & 3,901 & 3,680 \\
\hline Sugarcane & 1,191 & 1,297 & 1,530 \\
\hline Milk & 745 & 729 & 7,500 \\
\hline Beef & 506 & 471 & 520 \\
\hline Pork & 1,311 & 1,272 & 1,310 \\
\hline Chicken & 1,459 & 1,575 & 1,460 \\
\hline Eggs & 2,519 & 2,601 & 2,410 \\
\hline Fish & 3,769 & 3,175 & 3,870 \\
\hline
\end{tabular}

Source: MAFF: The basic plans for food, agriculture and rural areas, Food balance sheet.

Notes: 1) Rice does not include rice for rice flour or rice for feed.

22) The target value for seafood (edible) is the value for FY2027 of the Basic Plan for Fisheries (2017).

\section{Research Results of the National Agriculture,} Forestry and Fisheries Policy Research Institute

According to a study on food consumption prospects, the proportion of cooked food expenditure will rise and food externalization is expected to progress further (National Institute for Policy Research, Agriculture, Forestry and Fisheries, 2014a; Yakushiji, 2017).

According to research on the trend of vegetable processing and commercial use, the trend of processing raw materials and commercial foods continues to progress. In the future, it will be necessary to strengthen production and supply in response to demand for processing and commercial use (Kobayashi, 2018).

According to a study on community farming organizations, communities that have been established as branch management type community farming organizations do not have individual business farmers that can accept the farmland of farmers who are expected to leave the farm in the future. An organization has been born that takes over the farmland that is fluidized. (National Agriculture, Forestry and Fisheries Policy Institute, 2015).

According to the analysis for the farm organizational management body using the census of agriculture, the accumulation of paddy fields by lease is accelerating as the community farming organization becomes the corporation (Agricultural / Rural Structure Project Census Analysis Team, 2018a).

According to the analysis for large-scale farmers using the census of agriculture, large-scale paddy farmers among even individual farmers are increasing in number. The number of agricultural machines owned and the labor force are decreasing and efficiency is increasing (Agricultural and Rural Structure Project Census Analysis Team, 2018a). Among farmers with a farmland area of less than 15 ha and a head of household over 65 years old, there are a lot of farmers who have not been able to secure successors. It is important to transfer their farmland smoothly to the business farmer. (Hirabayashi, 2018).

According to the analysis on the use of farmland using the census of agriculture, large-scale farmers in East Japan and organized management bodies in West Japan accumulate farmland. Farmland owners may not be in rural areas, so it is necessary to use the Farmland Banks to accumulate farmland (Agricultural and Rural Structure Project Census Analysis Team, 2018b).

According to research on agricultural structure, organi- 
Principles and Policy Development of the Basic Law on Food, Agriculture and Rural Areas: Achievement and Future 39

zational efforts are progressing in organizations which have the purpose of organizational management.

Among the organizations which do not have the purpose of organizational management, there are some organizations whose organizational activities have been stagnant and they need to consider restructuring (National Institute for Policy Research of Agriculture, Forestry and Fisheries, 2010). In advanced areas of community farming, the acceptance of farmland by community farming organizations is reaching a peak. Community farming organizations have been established in areas where individual farmers mainly have been undertaking farmland, and movements to undertake farmland are progressing.

According to research on bioenergy, there is a difference in the perceptions of related parties regarding the value of digestive juice, a by-product (Hayashi et al., 2018).

According to the research on village prediction, small villages, villages with greatly decreasing population, and aging villages will increase in the future. In 2050, 30\% of villages in mountainous areas will have no children under the age of 14 (Agricultural, Forestry and Fisheries Policy Research Institute, 2014b; Hashizume, 2015).

According to research on the Direct Payment Systems for Hilly and Mountainous areas, this system has a direct good effect on agricultural production such as prevention of abandoned farmland and organization of farming. It has become an opportunity for village activities and also financial support (Hashizume et al., 2009).

\section{Conclusion}

The new basic law treats food, agriculture and rural areas as an integral unit, and makes concrete programs for measures deployment a basic plan. It is very significant that a mechanism to execute measures deployment flexibly according to the situation of economy and society was constructed by the basic plan.

It was revealed that such as the progress of production in response to the externalization of food, the concen-tration of measures to business farmers, the farming income stabilization measures, and direct payment to farmers in hilly and mountainous areas are steadily achieving an effect.

On the other hand,it is hard to say that the food selfsufficiency ratio has improved. It is necessary to deepen the discussion on the positioning of the calorie-based food selfsufficiency ratio especially, in the future basic plan.

\section{References}

Census Analysis Team of the Project on the Structure of the Agricultural Industry and Rural Regions (2018a) From the Analysis of Agricultural Producers, PRIMAFF Review No.84: 45 .

Census Analysis Team of the Project on the Structure of the Agricultural Industry and Rural Regions (2018b) From Analysis of Farmland, PRIMAFF Review No.86: 2-3.

Hashizume, N., A. Egawa, and Y. Takagishi (2009) Cusankan Chiiki niokeru Shurakukan Renkei no Genjo to Kadai: Chusankan Chiiki Chokusetsu Shiharai deno Fukusu Shuraku 1 kyotei ni Chakumoku Shite, Special Study for Administrative [Collaboration between Villages] Research Document, 1-65.

Hashizume, N. (2011) Suiden Nogyo no Kozo Henka to Sono Chiikisei ni Kansuru Tokei Bunseki, PRIMAFF Review No. 41: 6-7.

Hashizume, N. (2015) Jinko Genshoka niokeru Nogyo Shuraku no Henyo to Shorai Tembo: Shuraku Kozo no Dotai Bunseki to Sonzoku Kigu Shuraku no Shorai Yosoku, Rural Area Revitalization Project (Village Revitalization) Research Document.

Hashizume, N. (2016) The Systematized Problems of the Rural Policy: Focusing on the Direct Payment System to Farmers in Hilly and Mountainous Areas, Journal of Rural Economics 88 (1): 93-97.

Hayashi, T., M. Asai, and M. Yamamoto (2018) Differences in Interest between Arable Farmers and Dairy Farmers for CropLivestock Integration in Biogas Production Systems, The Frontiers of Agricultural Economics 21(1): 123-130.

Hirabayashi, M. (2018) Conditions for Scale Expansion of LargeScale Paddy Farming by Households in Japan Excluding Hokkaido, in Recent Years, Journal of Rural Economics 90 (1): 29-34.

Kobayashi, S. (2018) Vegetables for Processing and Food Service Uses in Japan - Current Trends and Future Directions, PRIMAFF Review (81): 2-3.

PRIMAFF (2010) Heisei 21nendo Suidensaku Chiiki niokeru Shurakueino Soshikito no Doko ni Kansuru Bunseki Kenkyu Hokokusho, Management Stabilization Project Research Document No. 6: 103-106.

PRIMAFF (2014a) Jinko Gensho Kyokumen Niokeru Shokuryo Shohi no Shorai Suikei, 41st Planning Committee of Food, Agriculture and Rural Area Policy Council (Document 3-1).

PRIMAFF (2014b) Jinko Gensho to Koreika no Shinko ga Noson Shakai ni Motarasu Eikyo: Seireki 2050nen niokeru Noson Jinko to Shuraku Kozo no Yosoku Kekka kara, 41st Planning Committee of Food, Agriculture and Rural Area Policy Council 
(Document 3-2).

PRIMAFF (2015) Tohoku Suiden Chitai niokeru Chiiki Nogyo no Ninaite to Kozo Henka: Akitaken oyobi Iwateken o Jirei toshite, Structural Analysis Project Research Document No. 5 [Actual Analysis].

PRIMAFF (2017) Heisei 28 nendo Koikiteki Renkei niyoru Nogyo Shuraku no Saisei ni Kansuru Kenkyu Hokokusho: Kumamotoken/Wakayamaken/Naganoken niokeru "Koikichiikisoshiki” no Genchi Chosa Kekka, Agricultural and Rural Areas Structure Project [Community Regeneration] Research Document No.1.

PRIMAFF (2018) Heisei 29 nendo Koikiteki Renkei niyoru Nogyo Shuraku no Saisei nikansuru Kenkyu Hokokusho: Aomoriken/ Iwateken/Gifuken Enashi niokeru "Koiki Chiiki Soshiki" no Genchi Chosa Kekka, Agriculturaland Rural Areas Structure Project [Community Regeneration] Research Document No.2.

Yakushiji, T. (2017) Shokuryo Shohi no Shorai Suikei, PRIMAFF "Juyo Kakudai ni Muketa Shuyo Nosuisambutsu Supply Chain niokeru Kadai to Torikumu Beki Hoko," Food Supply Project [Analysis by Item] Research Document No. 4: 3-35.

\section{List of Contibutors (As of March 31, 2019)}

Iwama Hiroshi, Counselor, Minister's Secretariat, MAFF

Kimura Takyuki, Senior Planning Officer of the Policy Division, Minister's Secretariat, MAFF

Okamoto Kichi, Deputy Director of the Policy Division, Minister's Secretariat, MAFF

Inoue Takashi, Planning Officer of the Food Security Office, MAFF Kato Humiaki, Planning Officer of the Policy Division, Minister's Secretariat, MAFF

Kashu Yuya, Planning Officer of the Policy Division, Minister's Secretariat, MAFF

Yoshida Yukisato, Director of Planning and Public Relations Office and Chief Policy Research Coordinator, PRIMAFF

Fujita Yoshinori, Research Coordinator, PRIMAFF

Kobayashi Shigenori, Senior Researcher, PRIMAFF

Hashizume Noboru, Senior Researcher, PRIMAFF

Hayashi Takeshi, Senior Researcher, PRIMAFF

Fukuda Ryuichi, Senior Researcher, PRIMAFF

Hirabayashi Mitsuyuki, Senior Researcher, PRIMAFF

Asai Masayasu, Researcher, PRIMAFF

Yagi Kohei, Researcher, PRIMAFF 